\title{
Verification of Efficacy of Bitoxybacillin/Bacillus thuringiensis on Red Spider Mite, Tetranychusurticae on Cut Roses
}

\author{
Kidist Teferra Yimame* Fikre Dubale Betree \\ Holeta Agriculture Research Center / Ethiopian Institution of Ethiopia, Addis Ababa, Ethiopia
}

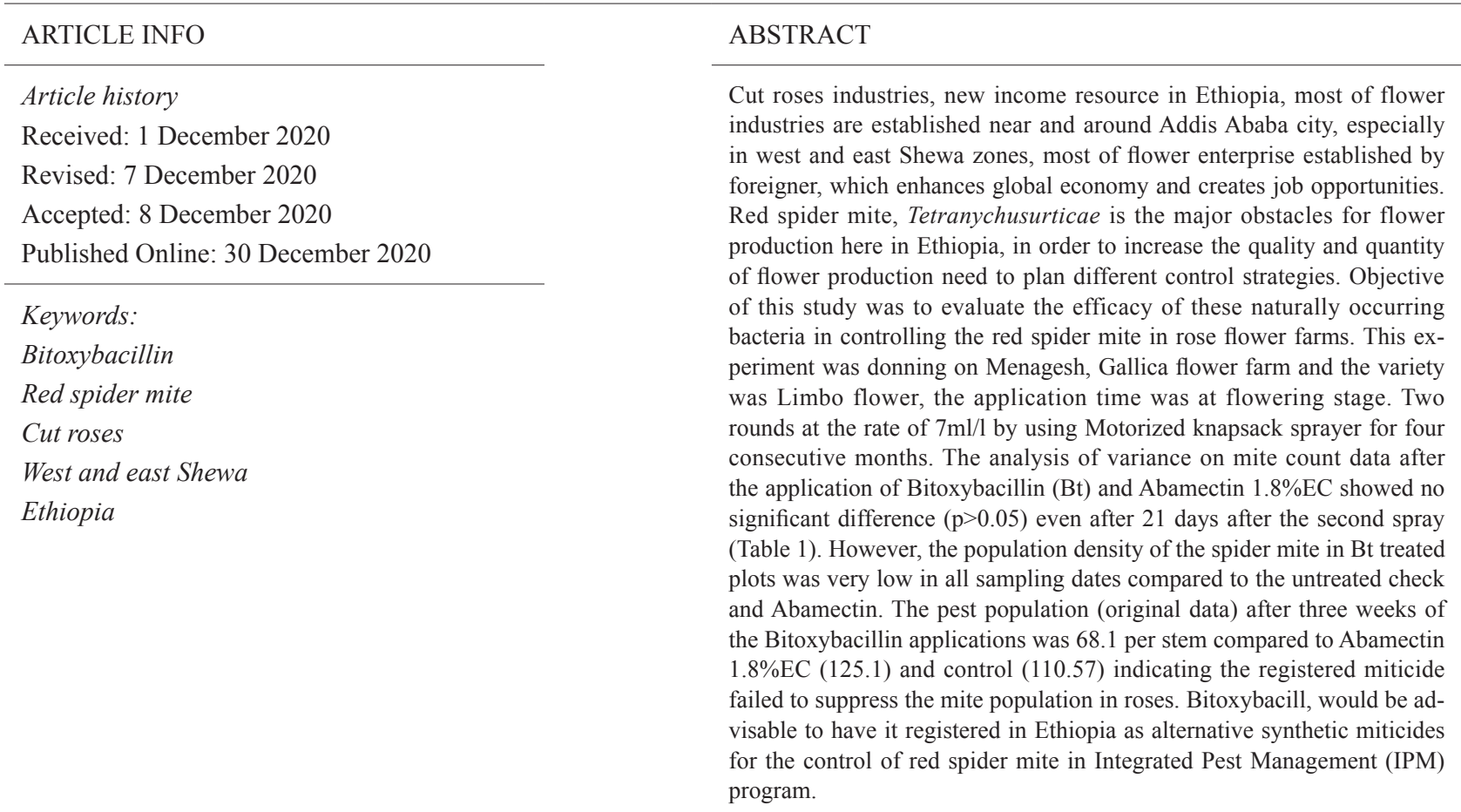

\section{Introduction}

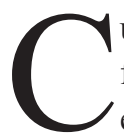
ut flowers are becoming very important and many flower farms have been established in west and east Shewa zones. The enterprise plays an important role in the global economy and creates jobs and earns the much-desired foreign currency to the country. The area under flower farms is increasing and the area coverage is estimated to be around 1000 ha.

Two-spotted spider mite, Tetranychusurticae Koch is among the major bottleneck of flower production through-

out the world. It is widely distributed and troublesome species recorded in Ethiopia ${ }^{[1]}$. All active stages (adults and nymphs) remove plant sap (undersurface of the leaves) causing tiny light spots (with speckled appearance). Loss in yield occurs when $30 \%$ of the leaf area damaged by spider mite ${ }^{[2,3]}$. Infestations will reduce the quality of cut flowers, and in case of severe infestations, the entire plant may die.

Acaricides have provided the major means of controlling infestations on mites and it is indisputable that

*Corresponding Author:

Kidist Teferra Yimame,

Holeta Agriculture Research Center / Ethiopian Institution of Ethiopia, Addis Ababa, Ethiopia;

Email: kidist.teferra@yahoo.com 
they have played a major role in flower production and is likely to do so for at least the foreseeable future. Since the establishment of these farms, a very wide range of different acaricides has been used to control the pest. These include dusting sulfur, Abamectin, Mitac, Dicofol, Apollo and many more. However, the repeated use of some products led to a build-up of resistance in mite population. This has resulted in a decrease in effectiveness of treatments that have been reported in Ethiopia in such a short period of time. Therefore, the development of alternative management strategies becomes paramount and the use of biological control agent's vis- á -vis microbial agents, parasitoids and predators. Predatory mites such as Phytoseiuluspersimilis and Amblyseiuscalifornicus were introduced to control spider mite in some flower farms ${ }^{[4]}$.

Thus there is an immediate need to change current crop protection strategies to ones that are based upon the use of IPM, rather than relying solely on pesticides.

Bacillus thuringiensis is a ubiquitous, gram-positive and spore-forming bacterium. During sporulation, it produces intracellular crystal proteins (cry proteins), which are toxic to insects. Because of its insecticidal activity, it has been used for nearly fifty years to control certain insect species among the orders Lepidoptera, Coloeptera, and Diptera.

The natural insecticide produced by the bacterium Bacillus thuringiensis (called " $B t$ ") has been used for decades by farmers to control insect pests and by the World Health Organization to kill mosquitoes without using dangerous chemical pesticides. The $B t$ is produced throughout the world and sold as a biological control agent in most countries where horticultural crops are grown. In 1995, worldwide sales of B. thuringiensis based insecticides were estimated at $\$ 90$ million representing about $2 \%$ of the total global insecticide market ${ }^{[5,6]}$. Therefore, the objective of study is to evaluate the efficacy of these naturally occurring bacteria in controlling the red spider mite in rose flower farms.

\section{Materials and Methods}

Location: Menagesha, Gallica flower farm

Variety: Limbo

Crop stage when bio-pesticide is applied: flowering

Target pest (Red spider mite, Tetranychusurticae Koch)

Trade Name: Bitoxybacillin

Scientific Name: Bacillus thuringiensis

Formulation: Bacillus thuringiensisvarthuringiensis bacterial spore (powder form)

Manufacturer: Sibbiopharm Ltd.

Dosage and frequency: Two rounds at the rate of $7 \mathrm{ml} / \mathrm{L}$

Application technique and duration: Motorized knapsack sprayer

Duration: Four months- Starting date: September 2016
Ending date: December 2016 Before the introduction of Bitoxybacillin the import permit was obtained from animal and plant Regulatory Directorate of the MoA Gallica flower facilitate to obtain the importation permit and provide logistics. The greenhouse was divided into 9 plots of $10 \mathrm{~m}$ by 6 rows receiving test bio-pesticde, Abamectin, standard acaricide and control replicated three times. Ten stems in each treatment/plot were randomly picked and tagged with colored labels for pre- and post- spray mite population count data throughout experimental period. The counts were made on the top, middle and lower leaves of each sampling stems. Spraying was initiated when the threshold of 4-7mites/leaf was attained. The data was analyzed using SAS software (Version 9.0) PROC GLM (2002) at $\mathrm{P}<0.05$. Differences between means were assessed using the least significance difference (LSD) test at $\mathrm{P}<0.05$ after necessary transformation was made.

\section{Results}

The result is summarized in Table 1. The analysis of variance on mite count data after the application of Bitoxybacillin $(\mathrm{Bt})$ and Abamectin 1.8\%EC showed no significant difference $(p>0.05)$ even after 21 days after the second spray (Table 1). However, the population density of the spider mite in Bt treated plots was very low in all sampling dates compared to the untreated check and Abamectin. The pest population (original data) after three weeks of the Bitoxybacillin applications was 68.1 per stem compared to Abamectin 1.8\%EC (125.1) and control (110.57) indicating the registered miticide failed to suppress the mite population in roses. The First two post spray counts of the spider mite also showed similar trend. The frequency of application of the bio-agent needs to be investigated in order to determine its economic optimum use as integrated management of the pest. Although there has been no significant difference among the treatments, the pest population was clearly reduced and kept below the threshold level in $\mathrm{Bt}$ treated plots compared to Abamectin $1.8 \% \mathrm{EC}(1.14 \mathrm{ml} / 1)$ and untreated control (Figure1).

Table 1. Mean pre- and -post spray mite count per stem of cut flower (transformed data, $\sqrt{(0.5+n)}$ )

\begin{tabular}{ccccccc}
\hline \multirow{2}{*}{ Treatment } & $\begin{array}{c}\text { Pre-spray } \\
\text { count }\end{array}$ & \multicolumn{2}{c}{$\begin{array}{c}\mathbf{1}^{\text {st }} \text { spray post } \\
\text { count }\end{array}$} & \multicolumn{2}{c}{$\mathbf{2}^{\text {nd }}$ spray post count } \\
\cline { 3 - 7 } & & 4DAS* & 10DAS & 5DAS & 12DAS & 21DAS \\
\hline Bitoxybacillin & $2.1 \mathrm{~A}$ & $1.82 \mathrm{~A}$ & $2.0 \mathrm{~A}$ & $2.3 \mathrm{~A}$ & $2.28 \mathrm{~A}$ & $4.3 \mathrm{~A}$ \\
Abamectin 1.8\%EC & $2.2 \mathrm{~A}$ & $2.32 \mathrm{~A}$ & $2.9 \mathrm{~A}$ & $3.6 \mathrm{~A}$ & $4.47 \mathrm{~A}$ & $6.06 \mathrm{~A}$ \\
Untreated check & $2.2 \mathrm{~A}$ & $4.67 \mathrm{~A}$ & $3.7 \mathrm{~A}$ & $4.9 \mathrm{~A}$ & $5.02 \mathrm{~A}$ & $5.73 \mathrm{~A}$ \\
LSD(0.05) & $\mathrm{NS}$ & 3.5 & $\mathrm{NS}$ & 2.6 & 2.74 & $\mathrm{NS}$ \\
$\mathbf{C V}$ & 46.6 & 31.4 & 37.9 & 21.1 & 41.6 & 18.8 \\
\hline
\end{tabular}

Note: $*$ DAS=Days after Spray 


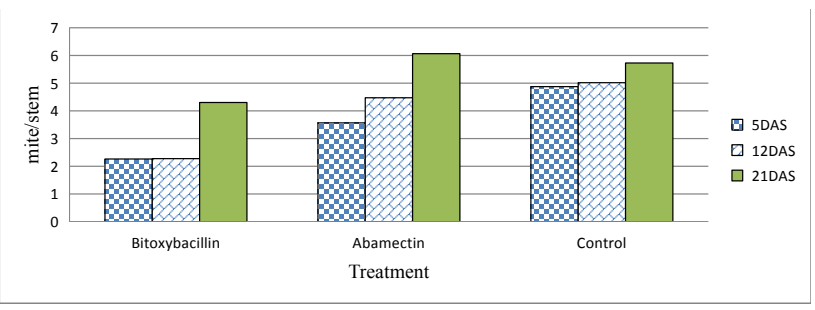

Figure 1. Post spray spider mite count per stem after 5, 12 and 21 days (transformed data)

Note: $*$ DAS $=$ Days after Spray

\section{Recommendation(s)}

Bitoxybacillin has a long history of success worldwide and has been registered for use on different insect pests of economic importance (caterpillars, aphids etc), it would be advisable to have it registered in Ethiopia as a relatively safe alternative to synthetic miticides for the control of red spider mite in IPM Program.

\section{References}

[1] Belder den A. Elings. On-farm evaluation of integrated pest management of red spider mite in cut roses in
Ethiopia: final report to the Ministry of Agriculture and Rural Development. 2009(4).

[2] Daniel E. Martinl., Mohamed A. Latheefl., Juan D. Lopezl. Evaluation of selected acaricides against two spotted spider mite (Acari: Tetranychidae) on greenhouse cottonusing multispectral data. Spring International Publishing Switzerland (outside the USA). 2015(1).

[3] Farman Ullah, Joon-Ho Lee, Farhatullh. Evaluation of cucumber (Cucumis sativus L.) accessions (cultivars and lines) against the two-spotted spider mite (Tetranychus urticae Koch.) and kanzawa spider mite (T. kanzawai Kishida, Acari: Tetranychidae). Songklanakarin J. Sci. Technol., 2006, 28(4).

[4] Hussey, N.W., Parr, W.J. The effect of glasshouse red spider mite (Tetranychus urticae, Koch) on the yield of cucumbers. J. Hort. Sci., 1963, 38: 255-263.

[5] Lambert B, M Peferoen. Insecticidal promise of Bacillus thuringiensis. Facts and mysteries about a successful biopesticide, 1992, 42: 112-122.

[6] Schnepf, N Crickmore, J Van Rie, D Lereclus, J Baum, J Feitelson, D R Zeiglerand D H Dean. Bacillus thuringiensis and its pesticidal crystal proteins. National library of medicen, 1998, 62(3): 775-806. 